\title{
Three Perspectives of Planning, Implementation, and Consistency in Instructional Coaching
}

\author{
Judith Tanner \\ University of Phoenix \\ Lisa Quintis \\ Walden University \\ Thomas Gamboa Jr. \\ University of Phoenix
}

\begin{abstract}
School administrators are choosing or required to implement instructional coaching on their campuses to improve student-learning opportunities. The school community must be aware that effective instructional coaching is job embedded, encourages teachers to become reflective practitioners, and requires time to commit to the implementation. School administrators must support instructional coaches by ensuring there is significant time allotted to provide coaches time in the classroom to observe, provide feedback, and support classroom teachers in their practice and reflection. Instructional coaches build trust and rapport with the instructional staff by implementing best-practice protocols, providing feedback, and planning the next steps. The instructional staff must be disposed to take the feedback and be willing to implement best practices and reflect upon the process. This article reflects each author's personal experiences in their roles as a school administrator, instructional coach, and classroom teacher with the distinct focus on instructional coaching from the practitioners' diverse perspectives. Current research on instructional coaching is examined and discussed. Best practices for classroom implementation of instructional coaching are reviewed. The article concludes that implementing instructional coaching in a school setting requires the school administrator to engage all stakeholders to understand the diverse perspectives of the individuals involved in the process. Implementing instructional coaching in a school setting must include the instructional process and student achievement as priorities.
\end{abstract}

Keywords: instructional coaching, student achievement, best practices, reflective practitioners

\section{Introduction}

Using instructional coaching as a form of professional development to improve teacher quality has significantly changed how teachers approach their craft. According to Cassidy, Garrett, Maxfield, and Patchett (2009), educational leaders have used instructional coaching in schools for decades, but it has continually evolved over time to adapt to the needs of schools and the changes in the instructional process of modern schools. The implementation of instructional coaching has increased due to the current state of data-driven schools, higher teaching standards, and increased teacher accountability (Knight, 2006). Therefore, when examining the planning and implementation of instructional coaching, it is important to reflect upon the diverse perspectives of those engaged in and affected by the instructional coaching process. 
Using professional development opportunities to improve teacher quality and instructional practices has been a consistent component of the educational system in the United States and other countries for many years (Knight, 2006; Kowal \& Steiner, 2007b; Quick, Holtzman, \& Chaney, 2009). However, a shift has occurred in the delivery of teacher professional development from 1-day workshops to an implementation method and to a more structured, ongoing, and individualized professional development that accommodates school, student, and teacher needs (Chamberlain, 2008; Chou, 2011; Dash, Magidin de Kramer, O'dwyer, Masters, \& Russell, 2012; Elder \& Padover, 2011; Guskey, 2002; Heitin, 2011; Knight, 2006; Kowal \& Steiner, 2007b; Opfer \& Pedder, 2010; Pradere, 2007). The purpose of this article is to examine current research on instructional coaching and provide reflection through three perspectives on planning, implementation, and consistency to seek best practices for the future use of instructional coaches by educational leaders. Each author presents one of the perspectives: The administrative perspective is provided by Judith Tanner, EdD, who is a retired elementary administrator; the prospective of instructional coach is given by Lisa Quintis, EdD, who is a district instructional specialist; and finally, Thomas Gamboa Jr., EdD, who is a High School Active Learning Leader with 18 years of experiences as a classroom teacher, offers the teaching perspective.

\section{Administrative Perspective}

\section{School Administration and Instructional Coaching}

Educational research includes assertions that an effective school administrator can positively affect a school (Hall \& Simeral, 2008; Marzano, Waters, \& McNulty, 2005). Any type of school change hinges on the words and actions of the principal or the school administrator. The principal's active support for an initiative such as using an instructional coach to improve best practices for teachers largely determines an instructional coach's degree of impact (Poglinco, Bach, Hovde, Rosenblum, \& Saunders, 2003).

Cotton (2003) described effective school leaders using 25 categories. The 25 categories included several directly tied to instruction, and Cotton indicated effective school administrators must ensure a school has a vision and goals focused on high levels of student learning; high expectations for student learning; a positive and supportive climate with good communication and interaction; shared leadership, decision making, and staff empowerment; and strong, consistent instructional leadership. School administrators can effectively meet these goals by developing an instructional coaching model in which an instructional coach develops collaborative relationships with the principal and the teaching staff. The instructional coach models best practices in the classroom with the teacher observing. The instructional coach then observes the teacher teaching a similar lesson and coaches and mentors the teacher as he or she improves instructional practices (Knight, 2007).

As a school administrator, Tanner's most positive experience was working with an effective school instructional coach who was an integral part of the leadership and instructional team. The effective instructional coach worked hard to develop positive working relationships with the instructional staff and spent quality time in classrooms. The instructional coach modeled, demonstrated, observed, and coached teachers with the intent of improving teaching practices to affect student success. The instructional coach used the instructional model throughout the year in conjunction with continually collected student data that led to improved student achievement on benchmark assessments in reading and math in all kindergarten through fifth-grade classes.

Tanner's experience working with an ineffective instructional coach was the opposite. The ineffective instructional coach pretended to be part of the leadership and instructional team while only reluctantly following the coaching model. The relationship with the instructional staff was contentious because the instructional specialist did not want to model, demonstrate, observe, or coach in specific classrooms when asked to do so by the administrator. The coach was often rude and 
negative (i.e. disrespectful, lack of empathy) to teachers when visiting their classrooms, which caused a rift between the instructional coach, administration, and other instructional staff. Student data in reading and math on benchmark assessments did not improve, and student success was at risk.

Many educators are using emerging research that indicates improving teacher quality leads to improved student achievement; these educators are embracing the idea of hiring an onsite staff developer to teach the teachers (Hall \& Simeral, 2008). According to the instructional coaching model, and the model implemented when Tanner was the school administrator, the instructional coach, with the school administrator, helps the school community begin crucial conversations about student learning that center on student work and data. As the team members-consisting of the coach, the administrator, and the teaching staff-analyze the data together, teachers have the opportunity to develop a common understanding of student proficiency, common misconceptions of students, and effective instructional strategies (Strahan, 2003).

The relationship between the school administrator, the instructional coach, and the teaching staff is critical to the success of this model. A single factor common to successful change is that relationships improve. Schools tend to be more functional when the relationships between the school administrator, the instructional coach, and the teaching staff improve (Goleman, Boyatzis, \& McKee, 2002). When school administrators, teachers, and the instructional coach work together, student achievement increases (Van Pelt \& Poparad, 2008). When school administrators, teachers, and the instructional coach do not work together, student achievement tends to stagnate because the team is dysfunctional. Such contentious relationships can put student success at risk. At the school level, it is vital to consider how to include the instructional coach in the leadership framework. The coach's purpose is always the same: to help move school and teacher goals forward (Sandvold \& Baxter, 2008).

\section{Administrators and Their Relationships With Instructional Coaches}

School change always hinges on the words and actions of the school administrator. When the school administrator supports an initiative, it is usually successful. When an instructional coach is placed on a campus, the school administrator's support determines whether the reform initiative will be successful (Wren \& Vallejo, 2009). For an instructional coach to be effective, the school administration must play an active role in selecting the most effective instructional coaches.

The school administrator is the school leader and determines the degree to which coaches have direct interactions with teachers. The engagement of the instructional coach within classrooms in professional development opportunities and during professional learning communities is critical to the model's success. The more removed coaches are from teachers' work in classrooms, the less likely they will affect teaching and learning (Kinnucan-Welsch \& Grogan, 2006).

\section{Professional Development}

One of the school administrator's most important tasks is to collaborate and develop professional development that will support teachers and help them facilitate student success. Darling-Hammond (2009) described research by Corcoran, McVay, and Riordan (2003) and by Supvitz and Turner (2000) that showed increased student achievement was associated with more intense participation by teachers in professional development and with greater exposure of students to the resulting reform-based instruction.

An effective professional development model, which is based on research, that was used in Tanner's elementary school involved teachers working together and engaging in continual dialogue to examine their practice and student performance and implementing instructional practices that were more 
effective (Darling-Hammond, 2009). When a collaborative relationship between the instructional coach and the building administrator is added to the model of working together and engaging in continual dialogue, the model is extremely effective (Knight, 2007).

\section{Instructional Coaching Perspective}

Improving classroom instruction and student learning necessitates that school administrators cultivate the individual as well as the collective capacity of teachers, as collaboration among teachers is one of the fundamental strategies needed to build capacity (Fullan, 2011; Hargreaves \& Fullan, 2013). Coaching provides the potential to foster collaboration. An essential factor of coaching is promoting collegial dialogue or coaching conversations about classroom practice (Denton \& Hasbrouck, 2009; Rodgers \& Rodgers, 2007). One of the most profound and rewarding incidents in Quintis' coaching experience was embarking on an inquiry-based book study that involved side-byside coaching with a group of teachers in Grades 3 through 6. Quintis and the teachers used the book Study Driven: A Framework for Planning Units of Study in the Writing Workshop (Ray, 2006), and they met once per week to discuss the text, share insights and learning as they implemented the work in the classrooms, and share anecdotal stories about students' writing. They planned the book study with side-by-side coaching so that Quintis was in each teacher's classroom for writing instruction once or twice per week. At the beginning of the book study, a third-grade teacher shared with her how reading Study Driven (Ray, 2006) was changing the way she thought about the writer's workshop. After reading just the first two chapters, she stated, "This just makes such sense, it's so logical to teach this way." The book study affected the way the teacher viewed her approach to teaching writing. This is the shift instructional coaches hope to see teachers make, and the teacher was able to read about a new instructional practice, take it back to her classroom and apply it, and receive support by Quintis as the instructional coach and by her peers who also participated in the learning. During the coaching, Quintis and the teachers would share student conversations, notes from their conferences, and their insights into the writing approach and then plan the next steps based on what they saw each day.

Researchers have indicated that one area in which instructional coaches can be most valuable is increasing teachers' awareness and knowledge of best practices (L'Allier \& Elish-Piper, 2007; Manzo, 2005; Saphier \& West, 2010). The focus is not only on improving student learning but also on building teachers' knowledge base of current best practices and supporting them as they adapt and implement new instructional approaches (Kinnucan-Welsch \& Grogan, 2006; Quintis, 2011). An example comes from a dialogue that occurred during the inquiry-based book study. The teachers shared how they recognized the need for repeated immersions in the text of the genre before they began naming it with students. Another idea that surfaced was that the teachers realized that students would write an approximation of their vision for a piece, and teachers need to accept this. The discussion provided the teachers a fresh way to look at how to hold students accountable in their writing.

\section{Implementation and Reflective Practice}

An important practice for working with teachers is to engage them in conversation to pave the way for them to open up about concerns in student learning or classroom instruction. Denton and Hasbrouck (2009) and Rodgers and Rodgers (2007) indicated that reflective dialogue and collegial conversations with opportunities to share insights with colleagues have an impact on teacher beliefs about student learning and their own practice. When teachers have the opportunity to reflect systematically on their experiences and practice, they begin to understand what their students do and why. This structured reflective conversation (Coskie, Robinson, Riddle-Buly, \& Egawa, 2005) helps teachers clarify why they are doing what they are doing with regard to their classroom instruction and provides insight into ways they can change their practice to make it more effective. 
An example that echoes this idea came from a teacher's reflective statement on the book study and coaching experience and her own learning about approaching writing with students:

Before I had read Study Driven, I would have told the student that he had to use words to describe the differences in jet propulsion and propellers. But today, I realized that informational texts use illustrations for just that purpose. So rather than tell the student what to do, I led him back to the examples from "real" texts.

Coaches can provide opportunities and support for teachers' reflection on both the content learned and the learning process.

Brown et al. (2007) noted that effective coaches make providing time for one-on-one work with teachers a high priority and use a protocol to guide the conversation between the instructional coach and the participating teachers throughout the process. These protocols include the prebrief and planning of a classroom observation. During the observation, an instructional coach takes notes based on the look-fors decided upon by the teacher and the coach. The protocol also includes a debriefing and reflective conversation with the teacher on what the coach observed, focusing on what the teacher is realizing about his or her own learning that is having an impact on his or her thinking and classroom practice and then planning for the next steps. At one school, Quintis worked with a kindergarten team, and each teacher chose something different to work on in the classroom. Each teacher brought data (student evidence) to a coaching preconference and, based on the data, chose an area of focus. From there, she planned an initial observation with each teacher and they decided on a particular look-for, followed by the observation and debriefing of the observations, and then planning for coaching next steps. One teacher who chose to work on math wanted to understand what students could do in number sense and math fluency if she created differentiated groups based on what she saw in their early work. Together, they referenced a kindergarten math resource and planned four differentiated groups. Quintis began her weekly coaching observations based on preplanned look-fors, and she followed up by debriefing and planning the next steps. From the outset, the teacher was motivated when she learned that by observing the members of each group during their work time and taking notes on what she noticed students could do or where there were gaps, she could immediately respond and adjust her instruction. In their final debriefing, the connection she made to improved student learning was that by consistently assessing student work and using the information to drive instruction, she was able to meet more student needs. She also reflected that she saw value in using anecdotal notes to decide on strategy groups and whole-group instruction.

One teacher chose to work on writing with her kindergarten students, as the student evidence and classroom observations indicated the students were not progressing in their writing. The first observation and feedback helped the teacher see students were not sure how to generate ideas, so they focused her coaching on that first. They planned a modeling lesson where the teacher thought aloud, told students a story, and then allowed students to share stories with each other to generate ideas to write about. In the debriefing, she realized that modeling how storytelling generates ideas enabled students to start writing based on the story they told their peers. They utilized a rubric to monitor students' early writing growth from drawing pictures of their stories, to students who could draw and had begun to label, and finally to students making approximations with sentences by stretching out sounds. The feedback provided based on each week's observation and the opportunity to plan lessons collaboratively and look for specific evidence of how the writing went led the teacher to be deliberate in her planning and modeling of the lesson for her kindergarten students. Because they looked at specific areas of how to engage kindergarten students in early writing, she reflected at the end of the coaching cycle that she had never appreciated what an impact having someone assist her in looking at students' writing on a daily basis would have on students' ability in, and attitude toward, writing. 
The partnership between coach and classroom teacher emphasizes feedback focused on the implementation of strategies to improve student achievement (Denton \& Hasbrouck, 2009). Researchers have indicated that effective coaches positively affect classroom instruction (Keller, 2007; Manzo, 2005; Saphier \& West, 2010; Shanklin \& Rainville, 2007). Coaching offers continuous support, intensive one-on-one professional learning opportunities, and ongoing feedback for classroom teachers (Knight, 2006; Saphier \& West, 2010).

\section{Conclusion to Instructional Coach Perspective}

The goal of coaching is to move educators toward precision teaching, and a means of orchestrating this is to involve teachers in new learning (Neufeld \& Roper, 2003). Coaching may also be the impetus that propels thinking forward and challenges teachers' ideas and established assumptions related to instruction and learning, which might lead to a heightened awareness by teachers of how and why change is necessary to meet the needs of students. The following teacher reflection demonstrates that thinking:

We all referred back to the part of Study Driven, where the author reminds us that in order to write something "real" students have to spend a lot of time reading, immersed in what that genre looks like. We all agreed this was a powerful place for us in our study of Study Driven.

Because the group of teachers involved in the book study had many opportunities and a lot of time for dialogue, reflection, and sharing their learning, there was also an impact on teaching practices of writing and consequently a positive impact on how students experienced writing. Fullan and Steigelbauer (1991) contended the change agent, who was the instructional coach, is the teachers' continued means of support in the implementation process. Change agents can be most successful when they help teachers integrate new initiatives into existing programs and customize the implementation to teachers' specific needs (Ellsworth, 2000).

\section{Teaching Perspective}

Teachers understand that professional development is essential in improving their professional skills and practice (Darling-Hammond, 2009; Guskey, 2002). Reform needed in the educational systems requires rewarding teachers for their knowledge and skills while providing support and access to ongoing quality professional development for continued growth that has been the impetus for a shift from the workshop-to-implementation method to ongoing professional development in the form of instructional coaching that can result in apprehension, confusion, and even resistance (Darling-Hammond, 2000). Creating change in teachers' professional practices requires systemic and engaging professional development that empowers teachers to change their beliefs and instructional practices (Guskey, 2002; Harris \& Hofer, 2011; McLeskey, 2011).

\section{Opening the Classroom}

Marzano (2011) noted that failing to clarify that coaching visits are not evaluative but instead a facilitation of reflection to improve instructional practices can impede the coaching process. When instructional coaching was implemented on Gamboa's campus, he was initially hesitant because he and many of his peers had only experienced visits as a component of their teaching evaluation. The implementation of instructional coaching on their campus involved the department chair becoming the instructional coach and having only limited teaching duties. Having a high regard for this individual as a professional educator did not make the initial entry into the classrooms easy for the teachers or for him. The first time he entered Gamboa's class, although they respected each other highly, Gamboa still felt a slight apprehension. Furthermore, after discussing the process with him, he confided that it was challenging for him as well, because some teachers were hesitant and even 
resistant to the instructional coaching process. As he continued to enter classrooms, focus on instructional practices, and build trust by reiterating that the process was about improvement, not evaluation, the teachers began to see more engagement and greater acceptance of the instructional coaching process. Initial entry of an instructional coach into the classroom may involve challenges or even resistance. However, with consistency, professionalism, and a focus on improving the instructional process through nonevaluative observations fostered by a trusting relationship between the teacher and instructional coach, schools can overcome the isolation of teaching (Elder \& Padover, 2011; Kowal \& Steiner, 2007b; Zwart, Wubbels, Bergen, \& Bolhuis, 2007).

\section{Teacher Personalities and Experiences}

Teaching is both a science and an art, where having content knowledge does not guarantee that one can effectively instruct others in a manner that facilitates content retention (Marzano, 2010).

Therefore, individual teachers all have their own personalities and experiences that in turn establish individual teaching styles. Educational leaders must understand these complexities as they plan and implement instructional coaching.

The unique characteristics of individual teachers and content area departments must be factored into both planning and implementation. Composition of content area departments may affect the success of instructional coaching. Factors such as teacher involvement in extracurricular activities and their teaching duties may lead to more acceptance of the feedback provided as a component of the instructional coaching process. Furthermore, other factors, such as technological skills, gender, and teaching experience, may contribute to the acceptance or resistance of the instructional coaching process (Ahrend, Diamond, \& Gillwebber, 2010; Akhavan, 2011; Elder \& Padover, 2011; Elish-Piper et al., 2008; Gamboa, 2014; Martin-Berry, 2003; Rock, Gregg, Gable, \& Zigmond, 2009; Rock, Zigmond, Gregg, \& Gable, 2011). From the teachers' perspective, it is important for educational leaders to assess the diverse skills, personalities, and experiences of teachers as elements of the framework for the instructional coaching program in their organization.

\section{Effective Feedback}

One of the most significant factors for creating changes in teachers' practices is providing feedback to reflect and refine teaching practices. Teachers understand the relationship between instructional practices and student achievement; thus, when provided data to support the need for change, teachers are much more accepting of instructional coaching (Datteri, 2011; Elder \& Padover, 2011; Guskey, 2002; Murray, Ma, \& Mazur, 2009). When a process for providing feedback to teachers does not engage teachers with meaningful content or a process for reflection, the effect on changing teachers' practices and student achievement may be minimal or nonexistent (Chamberlain, 2008; Elder \& Padover, 2011; Gamboa, 2014; Murray et al., 2009; Otto, 2009; Quintis, 2011; Stover, Kissel, Haag, \& Shoniker, 2011). Therefore, campus principals must carefully plan the methods and tools to facilitate the instructional coaching process that delivers feedback that engages teachers in the process and demonstrates a need to change teaching practices to improve student achievement.

The use of effective feedback on Gamboa's campus was a fundamental factor in the success of the instructional coaching process, as during his tenure they had two instructional coaches. The initial instructional coach wrote the observations and then set a time to sit down with the teacher to go over the observations and have a collegial discussion on the instructional process to improve future instruction. The second instructional coach wrote observations on a form and left the results in the teachers' mailboxes for them to review, which was not an effective means of communicating what she saw, and this instructional coach did not collaborate with the teachers on how to improve the instructional process. The failure to communicate effectively and provide effective feedback created negative opinions about the instructional coaching process among teachers. Experiencing feedback in an impersonal and evaluative format from the second instructional coach contrasted with the 
effective feedback provided by the first instructional coach that teachers valued and expressed interest in continuing, and this contrast led to the demise of the effective instructional coaching program on campus.

\section{Time Constraints}

As educational systems around the world evolve to meet the changing workforce demands and requests for educational reform, many of the supplemental duties required in the data-driven age of accountability have put a significant time constraint on teachers (Chamberlain, 2008; DarlingHammond, 2000; Fullan, 2009; Quintis, 2011; Rossides, 2004; Shidler, 2009; Terry, 2010; Varlas, 2010). As more has been required of teachers, their ability to have time to plan, reflect, and implement new teaching practices effectively has become more difficult (Bean, Draper, Hall, Vandermolen, \& Zigmond, 2010; Chamberlain, 2008; Darling-Hammond, 2012; Darling-Hammond \& Rustique-Forrester, 2005; Quintis, 2011; Zwart et al., 2007). Thus, principals must invest time into their master schedule to facilitate opportunities for professional growth for teachers through interactions with instructional coaches and other colleagues in professional learning communities to maximize the potential benefits of the instructional coaching process.

The decision to use an instructional coaching model for professional development in combination or as a replacement of the workshop-to-classroom implementation model must be made with the understanding that change is slow and must be supported over time. As noted by Guskey (2002), the old model of professional development was ineffective in creating teacher change in classroom instructional practices because of the lack of ongoing professional development and support necessary to create change in teachers' beliefs and understanding of best practices. Therefore, the instructional coaching process should be implemented with the caveat that immediate change will not occur; instead, through documented observations and feedback, it should become evident over time that teaching practices are changing with the intent to improve student achievement. To facilitate their understanding, teachers should receive professional development prior to the implementation of instructional coaching to clarify that the coaching process is not evaluative but reflective. According to Marzano (2011), the effective use of tools such as instructional rounds is founded on the understanding that feedback provides data for reflection about current practices that may become the impetus for changes based upon the needs of the organization and individual teachers. Effective instructional coaching requires the dedication of time and resources over a long period; thus, principals must make the decision to use instructional coaching carefully because it requires a long-term vision that can be adapted over time but not discarded or haphazardly implemented (Chou, 2011; Darling-Hammond, 2000; Duncan-Howell, 2010; Heineke, 2013; Hessee, 2011; Linder, Post, \& Calabrese, 2012; Lujan \& Day, 2010; Quick et al., 2009; Teague \& Anfara, 2012).

\section{Consistency}

The successful implementation and sustainability of instructional coaching as a form of professional development in an educational organization is influenced by many factors, but one of the most influential is consistency. Bruce and Ross (2008) asserted that teachers are more likely to sustain the change efforts presented during coaching if there is continual support and accountability. Teachers may be hesitant to implement changes when they are unsure or unskilled in new teaching practices or teaching technologies (Ertmer \& Ottenbreit-Leftwich, 2010; Hammond et al., 2009; Hertzler, 2010; Keengwe, Onchwari, \& Wachira, 2008). When instructional coaching is implemented inconsistently or with diverse protocols across a campus and content areas, creating effective change in instructional practices can be difficult (Gamboa, 2014). Hence, before principals implement instructional coaching in their organizations, careful planning that addresses consistency in the establishment and use of protocols for coaching must occur and be continually examined to ensure 
the accountability of all stakeholders and maximize the effectiveness of feedback and the reflective process.

Gamboa was fortunate to participate in an instructional coaching process as a teacher on a campus through the initial implementation and then the transition to a new coach. During this time, he was also conducting his dissertation research, and one conclusion made based on his study and findings was that failing to remain consistent with the instructional coaching model on his campus may have been a significant factor that limited the success of not only the instructional coaching process, but also potentially student achievement (Gamboa, 2014). During the transition of educational leadership and instructional coaches, the previously successful format of instructional coaching was disregarded, as the new instructional coach was assigned more administrative duties and assigned to coteach classes of targeted students to help them improve on state testing. Educational leadership's focus on a targeted student population and not on the instructional coaching process led to a lack of consistency that negatively affected the potential success of the instructional coaching program on the campus (Gamboa, 2014).

\section{Teacher Perspective Conclusions}

Although instructional coaching has been used in educational organizations, the increasing amount of research on the effectiveness of instructional coaching has not led to a conclusion that instructional coaching improves instructional practices to the point of effectively improving student achievement (Knight, 2006; Kowal \& Steiner, 2007a). It is important to clarify that the same limited research also does not indicate that instructional coaching is ineffective. Hence, the authors conclude that there is potential for instructional coaching to be a powerful agent of change that enhances teaching practices and potentially improves student achievement if properly planned, implemented, and supported over a significant period, although further research on this topic must continue. Teachers want to grow continually and provide their students with the best learning opportunities (Heineke, 2013). Thus, campus principals should engage their teachers in collegial discussions about the value of instructional coaching in their organizations with the understanding that implementing instructional coaching will require hard work and dedication to the entire instructional coaching process from all stakeholders.

\section{Conclusion}

The reason for any teacher professional development has always been to improve student achievement by improving teacher quality (Darling-Hammond, 2014). As leaders of educational institutions face the challenge of preparing students to master the skills needed to compete in the modern globalized economy, they have begun to realize that professional development must be ongoing and individualized to meet specific teacher and campus needs (Chamberlain, 2008; DarlingHammond, 2000; Elder \& Padover, 2011; Opfer \& Pedder, 2010). Instructional coaching has become a widely used form of professional development because it provides the individualized attention needed by teachers and schools while also sustaining long-term growth through ongoing support.

The challenge for any educational leader when implementing a new initiative is to establish a culture that engages all stakeholders (Green \& Laura, 2002; Kotter, 2007; Schwahn \& Spady, 1998; Senge, 1996; Zimmerman, 2004). Instructional coaching requires a leader to facilitate the process and to engage stakeholders to ensure the intended instructional benefits of the instructional coaching process take place. Thus, school administrators choosing to implement instructional coaching on their campus must understand the diverse perspectives of the individuals involved in the process, such as teachers, instructional coaches, and their unique student population to determine and how these factors develop into a synergistic, focused form of professional development that can have a positive effect on the instructional process and student achievement. Although 
rooted in scholarly research, the gap in the research from the practitioners' perspective on instructional coaching provided the opportunity to reflect upon individual experiences and perspectives including two authors' dissertation research in the development of this article.

\section{References}

Ahrend, G., Diamond, F., \& Gillwebber, P. (2010). Virtual coaching: Using technology to boost performance. Chief Learning Officer, 9, 44-47. Retrieved from http://www.clomedia.com/2010/06/27/virtual-coaching-using-technology-to-boostperformance/

Akhavan, N. (2011). The effects of coaching on teacher efficacy, individual academic optimism and student achievement (Doctoral dissertation). Available from ProQuest Dissertations and Theses database. (UMI No. 3465395)

Bean, R., Draper, J., Hall, V., Vandermolen, J., \& Zigmond, N. (2010). Coaches and coaching in reading first schools. Elementary School Journal, 111, 87-114. doi:10.1086/653471

Brown, D., Reumann-Moore, R., Roseann, H., Jolley, B. C., Riffer, M., \& du Plessis, P. (2007). Making a difference: Year two report of the Pennsylvania high school coaching initiative. Philadelphia, PA: Research for Action.

Bruce, C., \& Ross, J. (2008). A model for increasing reform implementation and teacher efficacy: Teacher peer coaching in Grades 3 and 6 mathematics. Canadian Journal of Education, 31, 346-370.

Cassidy, J., Garrett, S., Maxfield, P., \& Patchett, C. (2009). Literacy coaching: Yesterday, today, and tomorrow. In J. Cassidy, S. D. Garrett, \& M. Sailors (Eds.), Literacy coaching: Research and practice: 2009 CEDER yearbook (pp. 15-27). Corpus Christi, TX: Texas A\&M.

Chamberlain, K. (2008). Case study: Professional development that enhances teaching and learning (Doctoral dissertation). Available from ProQuest Dissertations and Theses database. (UMI No. 3371525)

Chou, C.-H. (2011). Teachers' professional development: Investigating teachers' learning to do action research in a professional learning community. Asia-Pacific Education Researcher, 20, 421437.

Cororan, T., McVay, S. I., \& Riordan, K. (2003) Getting it right: the MISE approach to professional development. Philadelphia, PA: Philadelphia Consortium for Policy Research in Education.

Coskie, T., Robinson, L., Riddle-Buly, M., \& Egawa, K. (2005). From the coaches' corner: What makes an effective literacy coach? Voices From the Middle, 12, 60-61.

Cotton, K. (2003). Principals and students achievement: What the research says. Alexandria, VA: Association for Supervision and Curriculum Development.

Darling-Hammond, L. (2000). Futures of teaching in American education. Journal of Educational Change, 1, 353-373. doi:10.1023/A:1010034806982

Darling-Hammond, L. (2009). Recognizing and enhancing teacher effectiveness. International Journal of Educational and Psychological Assessment, 3, 1-24. Retrieved from https://drive.google.com/file/d/OByxuG44OvRLPeVFMamE3ekxuYXM/view

Darling-Hammond, L. (2012). Soaring systems. Education Review, 24, 24-33. Retrieved from http://www.aft.org/sites/default/files/periodicals/DarlingHammond.pdf

Darling-Hammond, L. (2014, June 30). To close the achievement gap, we need to close the teaching gap. Huffington Post. Retrieved from http://www.huffingtonpost.com/lindadarlinghammond/to-close-the-achievement_b_5542614.html 
Darling-Hammond, L., \& Rustique-Forrester, E. (2005). The consequences of student testing for teaching and teacher quality. Yearbook of the National Society for the Study of Education, 104, 289-319. doi:10.1111/j.1744-7984.2005.00034.x

Dash, S., Magidin de Kramer, R., O'dwyer, L., Masters, J., \& Russell, M. (2012). Impact of online professional development on teacher quality and student achievement in fifth grade mathematics. Journal of Research in Education Technology, 45, 1-26. doi:10.1080/15391523.2012.10782595

Datteri, S. (2011). Effect of instructional coaching on literacy achievement in the elementary classroom (Doctoral dissertation). Available from ProQuest Dissertations and Theses database. (UMI No. 3474096)

Denton, C., \& Hasbrouck, A. (2009). A description of instructional coaching and its relationship to consultation. Journal of Educational and Psychological Consultation, 19, 150-175. doi:10.1080/10474410802463296

Duncan-Howell, J. (2010). Teachers making connections: Online communities as a source of professional learning. British Journal of Educational Technology, 4, 324-340. doi:10.1111/j.1467-8535.2009.00953.x

Elder, D. L., \& Padover, W. (2011). Coaching as a methodology to build professional practice. Journal of Research in Innovative Teaching, 4, 138-144. Retrieved from http://www.nu.edu/assets/resources/pageResources/journal-of-research-in-innovativeteaching-volume-4.pdf

Elish-Piper, L., L'Allier, S., \& Zwart, M. (2008). Literacy coaching: Challenges and promising practices for success. Illinois Reading Council Journal, 37, 10-21. Retrieved from http://www.illinoisreadingcouncil.org/images/IRCJWinter2008.pdf

Ellsworth, J. (2000). Surviving change: A survey of educational change models. Retrieved from ERIC database. (ED444597)

Ertmer, P., \& Ottenbreit-Leftwich, A. (2010). Teacher technology change: How knowledge, confidence, beliefs, and culture intersect. Journal of Research on Technology in Education, 42, 255-297. doi:10.1080/15391523.2010.10782551

Fullan, M. (2009). Large-scale reform comes of age. Journal of Educational Change, 10, 101-113. doi:10.1007/s10833-009-9108-z

Fullan, M. (2011). Learning is the work. Retrieved from http://michaelfullan.ca/wpcontent/uploads/2016/06/13396087260.pdf

Fullan, M., \& Steigelbauer, S. (1991). The new meaning of educational change (2nd ed.). New York, NY: Teachers College Press.

Gamboa, T. (2014). Study of face-to-face and virtual instructional coaching with core content high school teachers and composite student achievement (Doctoral dissertation). Available from ProQuest Dissertations and Theses database. (UMI No. 3583984)

Goleman, D., Boyatzis, R. E., \& McKee, A. (2002). Primal leadership: Realizing the power of emotional intelligence. Boston, MA: Harvard Business School Press.

Green, S., \& Laura, P. (2002). Leadership self-efficacy and managers' motivation for leading change. Journal of Organizational Behavior, 23, 215-235. doi:10.1002/(ISSN)1099-1379

Guskey, T. (2002). Professional development and teacher change. Teachers \& Teaching, 8, 381-391. doi:10.1080/135406002100000512

Hall, P., \& Simeral, A. (2008). Building teachers' capacity for success. Alexandria, VA: Association for Supervision and Curriculum Development. 
Hammond, M., Crosson, S., Fragkouli, E., Ingram, J., Johnston-Wilder, P., Johnston-Wilder, S., . . Wray, D. (2009). Why do some student teachers make very good use of ICT? An exploratory case study. Technology, Pedagogy \& Education, 18, 59-73. doi:10.1080/14759390802704097

Hargreaves, A., \& Fullan, M. (2013). Professional capital: Transforming teaching in every school. JSD: The Learning Forward Journal, 34, 36-39. Retrieved from http://michaelfullan.ca/wpcontent/uploads/2013/08/JSD-Power-of-Professional-Capital.pdf

Harris, J., \& Hofer, M. (2011). Technological pedagogical content knowledge (TPACK) in action: A descriptive study of secondary teachers' curriculum-based, technology-related instructional planning. Journal of Research on Technology in Education, 43, 187-209. doi:10.1080/15391523.2011.10782570

Heineke, S. (2013). Coaching discourse. Elementary School Journal, 113, 409-433. doi:10.1086/668767

Heitin, L. (2011). Marzano on developing teachers. Teacher Professional Development Sourcebook, 5, 6. Retrieved from http://www.edweek.org/tsb/articles/2011/10/13/01marzano.h05.html

Hertzler, K. (2010). High school teachers' perceptions of the integration of instructional technology in the classroom (Doctoral dissertation). Available from ProQuest Dissertations and Theses database. (UMI No. 3414547)

Hessee, G. (2011). Coaching within a community of practice: The effects of one urban school's collaborative professional development model on teacher instruction and student achievement (Doctoral dissertation). Available from ProQuest Dissertations and Theses database. (UMI No. 3492279)

Keengwe, J., Onchwari, G., \& Wachira, P. (2008). The use of computer tools to support meaningful learning. AACE Journal, 16, 77-92. doi:10.1598/RT.59.5.2

Keller, B. (2007). Coaching teachers to help students learn. Education Week, 27, 22-24. Retrieved from http://www.edweek.org/ew/articles/2007/12/12/15coaching.h27.html

Kinnucan-Welsch, R., \& Grogan, P. R. (2006). Accountability by design in literacy professional development. The Reading Teacher, 59, 426-437. doi:10.1598/RT.59.5.2

Knight, J. (2006). Instructional coaching. School Administrator, 63, 36-40. http://www.aasa.org/SchoolAdministratorArticle.aspx?id=9584

Knight, J. (2007). Instructional coaching: A partnership to improving instruction. Thousand Oaks, CA: Corwin Press.

Kotter, J. (2007). Leading change. Harvard Business Review, 85, 96-103. Retrieved from https://hbr.org/2007/01/leading-change-why-transformation-efforts-fail

Kowal, J., \& Steiner, L. (2007a). Instructional coaching (Issue brief). Washington, DC: Center for Comprehensive School Reform and Improvement.

Kowal, J., \& Steiner, L. (2007b). Principal as instructional leader: Designing a coaching program that fits. Washington, DC: Center for Comprehensive School Reform and Improvement.

L'Allier, S. K., \& Elish-Piper, L. (2007). Ten best practices for professional development in reading. Illinois Reading Council Journal, 35, 22-27. Retrieved from http://www.illinoisreadingcouncil.org/images/IRCJournalWinter2006.pdf

Linder, R., Post, G., \& Calabrese, K. (2012). Professional learning communities: Practices for successful implementation. Delta Kappa Gamma Bulletin, 78, 13-22. doi:10.1007/s10833-006$0001-8$

Lujan, N., \& Day, B. (2010). Professional learning communities: Overcoming the roadblocks. Delta Kappa Gamma Bulletin, 76, 10-17. 
Manzo, K. K. (2005). States and districts send literacy coaches to the rescue. Education Week, 24, 20-21. Retrieved from http://www.edweek.org/ew/articles/2005/07/27/43coach.h24.html

Martin-Berry, R. (2003). Coaching virtually: Exploring factors that contribute to a successful outcome. Washington, DC: American Psychological Association.

Marzano, R. (2010). Representing knowledge nonlinguistically. Educational Leadership, 67, 84-86. Retrieved from http://www.ascd.org/publications/educationalleadership/may10/vol67/num08/Representing-Knowledge-Nonlinguistically.aspx

Marzano, R. (2011). Making the most of instructional rounds. Educational Leadership, 68, 80-82. Retrieved from http://www.ascd.org/publications/educationalleadership/feb11/vol68/num05/Making-the-Most-of-Instructional-Rounds.aspx

Marzano, R., Waters, T., \& McNulty, B. (2005). School leadership that works: From research to results. Alexandria, VA: Association for Supervision and Curriculum Development.

McLeskey, J. (2011). Supporting improved practice for special education teachers. Journal of Special Education Leadership, 24, 26-35.

Murray, S., Ma, X., \& Mazur, J. (2009). Effects of peer coaching on teachers' collaborative interactions and students' Mathematics achievement. Journal of Educational Research, 102, 203-212. doi:10.3200/JOER.102.3.203-212

Neufeld, B., \& Roper, D. (2003). Coaching: A strategy for developing instructional capacity. Washington, DC: Aspen Institute Program on Education.

Opfer, V., \& Pedder, D. (2010). Benefits, status and effectiveness of continuous professional development for teachers in England. Curriculum Journal, 21, 413-431. doi:10.1080/09585176.2010.529651

Otto, T. (2009). A case study: The influence of the Pennsylvania high school coaching initiative on the change of teachers' instructional practices and student achievement (Doctoral dissertation). Available from ProQuest Dissertations and Theses database. (UMI No. 3352436)

Poglinco, S., Bach, A., Hovde, K., Rosenblum, S., \& Saunders, M. (2003). The heart of the matter: The coaching model in America's choice schools. Retrieved from http://www.cpre.org/images/stories/cpre_pdfs/AC-06.pdf

Pradere, S. (2007). Effective staff development connected to increased student achievement (Doctoral dissertation). Available from ProQuest Dissertations and Theses database. (UMI No. 3258839)

Quick, H., Holtzman, D., \& Chaney, K. (2009). Professional development and instructional practice: Conceptions and evidence of effectiveness. Journal of Education for Students Placed at Risk, 14, 45-71. doi:10.1080/10824660802715429

Quintis, L. (2011). A phenomenological examination of barriers to implementing best teaching practices learned during coaching (Doctoral dissertation). Available from ProQuest Dissertations and Theses database. (UMI No. 3461463)

Ray, K. (2006). Study driven: A framework for planning units of study in the writing workshop. Portsmouth, NH: Heinemann.

Rock, M., Gregg, M., Gable, R., \& Zigmond, N. (2009). Virtual coaching for novice teachers. Phi Delta Kappan, 91, 36-41.

Rock, M., Zigmond, N., Gregg, M., \& Gable, R. (2011). The power of virtual coaching. Educational Leadership, 69, 42-47. doi:10.1177/003172170909100209

Rodgers, A., \& Rodgers, E. (2007). The effective literacy coach: Using inquiry to support teaching and learning. New York, NY: Teachers College Press. 
Rossides, D. (2004). Knee-jerk formalism: Reforming American education. Journal of Higher Education, 75, 667-703. doi:10.1353/jhe.2004.0039

Sandvold, A., \& Baxter, M. (2008). Fundamentals of literacy coaching. Alexandria, VA: Association for Supervision and Curriculum Development.

Saphier, J., \& West, L. (2010). How coaches can maximize student learning. Phi Delta Kappan, 91, 46-50. Retrieved from http://www.rbteach.com/sites/default/files/jons_lwest_coaching_kappan_dec2009-jan2010.pdf

Schwahn, C., \& Spady, W. (1998). Why change doesn't happen and how to make sure it does. Educational Leadership, 55, 45-47. Retrieved from http://www.ascd.org/publications/educational-leadership/apr98/vol55/num07/Why-ChangeDoesn't-Happen-and-How-to-Make-Sure-It-Does.aspx

Senge, P. M. (1996). Leading learning organizations. Training \& Development, 50, 36.

Shanklin, N., \& Rainville, K. (2007, November). Summary of research on literacy coaching from NRC 07. Retrieved May 10, 2017, from http://www.literacycoachingonline.org/library/resources /shanklinnrainvillek2007summaryofresearchonliteracycoachingfromnrc07.html

Shidler, L. (2009). The impact of time spent coaching for teacher efficacy on student achievement. Early Childhood Education Journal, 36, 453-460. doi:10.1007/s10643-008-0298-4

Stover, K., Kissel, B., Haag, K., \& Shoniker, R. (2011). Differentiated coaching: Fostering reflection with teachers. The Reading Teacher, 64, 498-509. doi:10.1598/rt.64.7.3

Strahan, D. (2003). Promoting a collaboration professional culture in three elementary schools that have beaten the odds. Elementary School Journal, 104. doi:10.1086/499746

Supvitz, J. A., \& Turner, H. M. (2000) The effects of professional development on science teaching practices and classroom culture. Journal of Research in Science Teaching, 37, 963-980. doi:10.1002/1098-2736(200011)37:9<963::AID-TEA6>3.0.CO;2-0

Teague, G., \& Anfara, V., Jr. (2012). Professional learning communities create sustainable change through collaboration. Middle School Journal, 44, 58-64. doi:10.1080/00940771.2012.11461848

Terry, K. (2010). Compliance, commitment, and capacity: Examining districts' responses to No Child Left Behind. Planning and Changing, 41, 80-109.

Van Pelt, J., \& Poparad, M. A. (2006). Revamping reading. School Administrator, 63, 31. Retrieved from http://www.aasa.org/SchoolAdministratorArticle.aspx?id=9566

Varlas, L. (2010). Education funding: Underwater and overdue for reform. Infobrief, 16, 1-6. Retrieved from http://www.ascd.org/publications/newsletters/policypriorities/vol16/issue3/full/Education-Funding@-Underwater-and-Overdue-for-Reform.aspx

Wren, S., \& Vallejo, D. (2009). Effective collaboration between instructional coach and principals. Retrieved from http://www.balancedreading.com/Wren_\&_Vallejo_Coach_Principal_Relatinships.pdf

Zimmerman, J. (2004). Leading organizational change is like climbing a mountain. Educational Forum, 68, 234-242. doi:10.1080/00131720408984635

Zwart, R., Wubbels, T., Bergen, T., \& Bolhuis, S. (2007). Experienced teacher learning within the context of reciprocal peer coaching. Teachers \& Teaching, 13, 165-187. doi:10.1080/13540600601152 
The Journal of Educational Research and Practice provides a forum for studies and dialogue that allows readers to better develop social change in the field of education and learning. Journal content may focus on educational issues of all ages and in all settings. It also presents peer-reviewed commentaries, book reviews, interviews of prominent individuals, and additional content. The objectives: We publish research and related content that examines current relevant educational issues and processes aimed at presenting readers with knowledge and showing how that knowledge can be used to impact social change in educational or learning environments. Additional content provides an opportunity for scholarly and professional dialogue regarding that content's usefulness in expanding the body of scholarly knowledge and increasing readers' effectiveness as educators. The journal also focuses on facilitating the activities of both researcher-practitioners and practitioner-researchers, providing optimal opportunities for interdisciplinary and collaborative thought through blogging and other communications.

Walden University Publishing: http://www.publishing.waldenu.edu 